\title{
Life on Mars (LoMars): A bibliometric study of current research and future perspectives
}

ARSHAD ALI ${ }^{\mathrm{a} *}$, MUHAMMAD S. SHAHID ${ }^{\mathrm{b}}$, IFFAT JABEEN ${ }^{\mathrm{c}}$, MOHAMED A.K. EL-GHALI ${ }^{\mathrm{a}}$

${ }^{a}$ Earth Sciences Research Centre (ESRC), Sultan Qaboos University (SQU), Al Khod, Muscat 123, Oman

${ }^{b}$ Department of Plant Sciences, College of Agricultural and Marine Sciences, Sultan Qaboos University (SQU), Al-

Khod, Muscat 123, Oman

${ }^{c}$ London, Ontario, Canada

* Corresponding Author: E-mail: arshadali@ squ.edu.om

ORCID: Arshad Ali: https://orcid.org/0000-0002-7087-0269

\section{Conflicts of Interest}

The authors declare no conflict of interest.

Author contributions

Arshad Ali and Muhammad S. Shahid contributed to the study conception and design. Material preparation, data collection and analysis were performed by Muhammad S. Shahid, Arshad Ali, and Iffat Jabeen. The first draft of the manuscript was written by Arshad Ali and all authors commented on previous versions of the manuscript. All authors read and approved the final manuscript. 


\begin{abstract}
A quest for life on Mars (LoMars) started in the early 1960s when several research articles were published by the most prestigious scientific journals. The rise in annual literature production started in the late 1990s, most likely associated with the launch of the National Aeronautics and Space Administration's (NASA) first Sojourner Rover in 1996. This trend predicts that the articles on Mars would further increase in the future given the fact that the recent launch and landing of the Mars 2020 Perseverance Rover is of utmost importance to find and understand the present or past life on the planet. So far, USA dominated the citations and collaborations with the rest of the world on Mars research given its facilities equipped with relevant infrastructure and researchers' capacity to explore the Solar System beyond Earth. Majority of these frequently cited papers report results of observational and theoretical research; however, the highly cited paper (MCKAY D. S. et al. 1996) is based on analytical studies of a unique Martian meteorite (i.e., Allan Hills 84001) found in the Antarctica. It is expected that the sample return mission associated with the Perseverance Rover could possibly increase the LoMars research exponentially in the coming decades if Martian samples are successfully brought back to Earth. Based on the total number of publications on LoMars, highly influential institute, author, and journal represent Caltech, McKay C. P., and Icarus, respectively. Both the institute and the author are directly affiliated with the NASA, suggestive of the leadership offered by the organization in LoMars research.
\end{abstract}

Key words: Bibliometric Analysis, Life on Mars, Water on Mars, Perseverance Rover, Mars 2020, Meteorite

\title{
Introduction
}

According to the Elsevier's abstract and citation database, Scopus, the first paper about 'Life on Mars' appeared in the scientific journal Science (LEVIN et al. 1962), opening the doors for a concerted multidisciplinary approach to explore another planet. In order to address the possibility of the presence of water and the existence of life on Mars, several studies came out during the 1960s (e.g., LEVIN et al. 1962; REA, 1963; OYAMA, 1963; SHIRK et al. 1965; HAWRYLEWICZ et al. 1967). Contemporaneous to these studies, the National Aeronautics and Space Administration (NASA) successfully launched its first flyby of Mars (Mariner 4) on 28 November, 1964 after a few unsuccessful attempts by the Soviet Union and NASA. Later, it captured and sent the first close-up images of Mars to Earth. The next decade (the 1970s) highlighted the successful launch of Viking 1 and Viking 2 landers in 1975 that provided important information about the atmosphere and surface of Mars with no conclusive evidence regarding the existence of life on the planet (LEVIN \& STRAAT, 1976). Along with remote exploration, a complementary understanding of Mars has been gained from detailed investigations of meteorites. Until the early 1980s, some meteorites were presumably considered as originated from Mars because of the chemical composition that is identical to the analysis done by the Viking landers (LEVIN \& STRAAT, 1976) and differences in geochemical characteristics from other common groups of meteorites. BOGARD \& JOHNSON (1983) provided direct evidence of a link between these anomalous meteorites and Mars after analyzing the trapped gasses in impact-related glass from Elephant Moraine 79001 (EET 79001) meteorite collected by ANSMET (i.e., US Antarctic Search for Meteorites program) in Antarctica. The obtained results from these gases (e.g., argon, krypton, xenon) closely resembled to those of the Martian atmosphere analyzed by Viking lander (BOGARD \& JOHNSON, 1983). Martian meteorite finds/falls are rare (i.e., as of 18 August, 2020, Meteoritical Bulletin Database contains 277 samples registered out of $63978=\sim 0.4 \%$ ) 
compared to other common types and, have so far provided important clues about water and life on Mars (MCKAY et al. 1996).

After launching flybys and landers, NASA successfully launched its first Rover, named Sojourner, to take the Martian exploration to the next level in the mid-1990s (4 December, 1996). Later, other Rovers including Spirit (10 June, 2003), Opportunity (8 July, 2003), and Curiosity (26 November, 2011), have also made successful landings on Mars. All these missions have provided an unparalleled understanding of the Martian geology and its landscape. Our motivation is the recent launch and landing of the NASA's Perseverance Rover, also known as Mars 2020, designed specifically to search for microbial life on Mars and first to cache samples from the Martian surface for future missions to bring them to Earth. With all the exciting space developments and prospects of human habitability on Mars, it is vital to evaluate the history and impact of the research on LoMars using statistical methods (i.e., bibliometric). In the present study, we will provide a literature overview of the LoMars research with the main emphasis on bibliographic variables including author(s), source journal, subjective keywords as well as citation scores (YOUNG \& BELANGER, 1983) in recognizing the most prominent articles, authors, journals, collaborations, and growth trends.

\section{Methodology}

\section{Literature search, data extraction and analysis}

A literature collection was initiated with a wide-ranging search of relevant articles on LoMars. The initial step was to determine the appropriate database, which would provide a full range of published articles on LoMars to be used for literature search. Elsevier's Scopus (ESc), a wide database containing peer-reviewed literature was used for bibliographic information of each document along with other publishing information necessary to carry out citation analysis of the field relevant to LoMars articles. In addition, ESc has broader article coverage compared to other web sources, thereby fit for our means to extract as much relevant information as possible. The relevant documents were searched in the abstract, title and authors' provided keywords by using a comprehensive list of important words used by the researchers involved in the literature on LoMars. The following final Boolean search has been carried out in ESc during August 2020, after the launch of Mars 2020 Perseverance Rover by NASA, and later updated on March 14, 2021: TITLE-ABS-KEY (("Life on Mars*" OR "Martian life*" OR "water on Mars*" OR "Martian Soil*" OR "SNC meteorites*" OR "Shergottite-Nakhlite-Chassignite*" OR "Shergottite Nakhlite Chassignite*" OR "Shergottites*" OR "Nakhlites*" OR "Chassignites*" OR "Martian meteorites*" )). This method provided more than seven thousand documents. In order to extract relevant articles, several filters were applied we kept only English journal articles while removing books, book chapters and conference proceedings. After applying all these filters as well as manually removing irrelevant articles, the final sample contained 660 articles published between the period of 1962 to 2020 . The academic data file recorded, such as the publication over time, authors' production over time, authorship, institutions, countries, journals, publication count, keywords, institution collaborations network and citation count were extracted from the Scopus database. The downloaded data file (full records and cited references) were exported into the R-based Bibliometrix interface, which is widely used for citation analysis (MARTY et al. 2020; ARIA \& CUCCURULLO, 2017). These articles have been published in diverse peerreviewed research journals, written by single or multiple authors from different countries (Table 1). The VOSviewer 
program was used to construct the network analysis between citation, country, and authors' collaborations (PERIANES-RODRIGUES et al. 2016).

\section{Results and discussion}

Overall results

Eleven search strings have been used to find the 660 documents on LoMars (Table 1). A total number of documents and the average citations per document reveal that the LoMars research has been cited for 22,242 times. In the earlyto mid-1990s, the annual number of articles has been increasing until the beginning of the $21^{\text {st }}$ century, from where onwards the publication output remained below 30 publications per annum with the exception of 2003 (35), 2011 (33), and 2019 (34). The rise in the number of publications in the 1990s could possibly be due to the launching of the first Rover, Sojourner (4 December, 1996). The spikes in the number of articles (Figure 1) may have been linked to the launching of NASA Rovers such as Spirit (10 June, 2003), Opportunity (8 July, 2003), and Curiosity (26 November, 2011). Presumably, the exceptional features of the Perseverance Rover compared to the earlier rovers would trigger the higher publication throughput in the future, and the spike in 2019 could be the beginning of yet another surge in LoMars research as previously observed in the 1990s. Over 20 publications per year began in 1998 (i.e., 23, Figure 1; Table 2) with only two articles cited for more than a hundred times (JAKOSKY \& SHOCK, 1998; SLEEP \& ZAHNLE, 1998), showing mean total citations per article (i.e., MTCpA) and mean total citations per year (i.e., MTCpY) equal to 32.9 and 1.5, respectively. A list of years with over 20 publications per year (Table 2) shows that the highest MTCpA (74.9) and MTCpY (6.3) values are associated with 2000 and 2015, respectively. Four of the total twenty publications in the year 2000 have been cited for more than 150 times (YEN et al. 2000; SKIDMORE et al. 2000; BENNER et al. 2000; WYNN-WILLIAMS \& EDWARDS, 2000), a potential factor of higher MTCpA, while a paper about hydrated salts on Mars (OJHA et al. 2015) has been cited for more than 300 times making the year 2015 with the highest MTCpY value (Table 2). The same paper also represents one of the highly-cited publications among the Top 10 papers regarding their average per year citations (APYC; Table 3). 
Table 1. Attributes of the sampled articles based on sources, contents, keywords, authors, and citations.

\begin{tabular}{|c|c|c|}
\hline Variables & Description & Results \\
\hline Documents & Total sampled documents & 660 \\
\hline $\begin{array}{l}\text { Average citations per } \\
\text { document }\end{array}$ & Total citations/ Number of documents & 33.7 \\
\hline Keywords plus (ID) & Word and phrases that appear in the titles of the article's references & 2835 \\
\hline Author's keywords (DE) & Total number of different keywords provided by the authors & 1062 \\
\hline Authors & Total number of different authors appearing in the sampled documents & 2006 \\
\hline Author appearances & $\begin{array}{l}\text { A total number of authors appearing in the sampled documents (note: one } \\
\text { author appearing in two papers counts for two authors). It is calculated as } \\
\text { the sum of the number of authors appearing in each paper }\end{array}$ & 2959 \\
\hline $\begin{array}{l}\text { Authors of single-authored } \\
\text { documents }\end{array}$ & $\begin{array}{l}\text { Number of documents that have been authored by one author (note: one } \\
\text { author may have written two or more "one author" papers) }\end{array}$ & 20 \\
\hline $\begin{array}{l}\text { Authors of multi-authored } \\
\text { documents }\end{array}$ & $\begin{array}{l}\text { Total number of authors contributing to documents with more than one } \\
\text { author }\end{array}$ & 120 \\
\hline Single-authored documents & Number of authors authoring alone (as single authors) & 1886 \\
\hline Documents per author & $\begin{array}{l}\text { The ratio of the total number of documents divided by the number of } \\
\text { authors }(=660 / 2006)\end{array}$ & 0.329 \\
\hline Authors per document & The ratio of authors over the documents $=2006 / 660$ & 3.04 \\
\hline Co-authors per documents & The ratio of author appearances over the documents $=2959 / 660$ & 4.48 \\
\hline Collaboration index & Total Authors of Multi-Authored Articles/Total Multi-Authored Articles & 3.74 \\
\hline
\end{tabular}

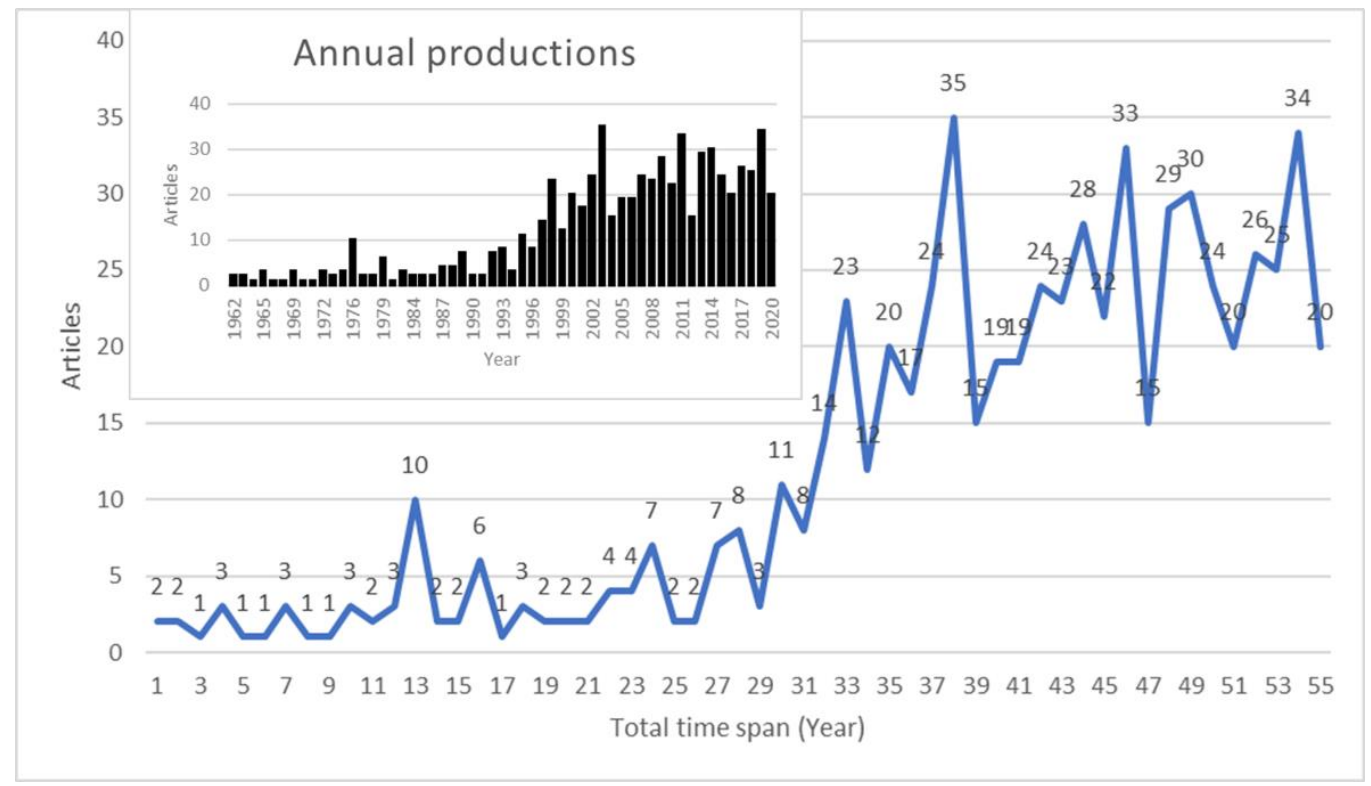

Figure 1. Annual article production during last fifty-eight years on LoMars research. 
Table 2. Total number of publications, citations, and average of total year citations and the whole citable durations.

\begin{tabular}{lllll}
\hline Year & NP & MTCpA & MTCpY & CY \\
\hline 2003 & 35 & 34.4 & 2.0 & 17 \\
2019 & 34 & 2.2 & 2.2 & 1 \\
2011 & 33 & 24.7 & 2.7 & 9 \\
2014 & 30 & 19.2 & 3.2 & 6 \\
2013 & 29 & 22.0 & 3.1 & 7 \\
2009 & 28 & 27.7 & 2.5 & 11 \\
2017 & 26 & 11.8 & 3.9 & 3 \\
2018 & 25 & 9.3 & 4.6 & 2 \\
2002 & 24 & 39.0 & 2.2 & 18 \\
2007 & 24 & 39.6 & 3.0 & 13 \\
2015 & 24 & 31.3 & 6.3 & 5 \\
1998 & 23 & 32.9 & 1.5 & 22 \\
2008 & 23 & 22.0 & 1.8 & 12 \\
2010 & 22 & 35.0 & 3.5 & 10 \\
2000 & 20 & 74.9 & 3.8 & 20 \\
2016 & 20 & 11.9 & 3.0 & 4 \\
\hline
\end{tabular}

Abbreviations: $\mathrm{NP}=$ total number of articles. $\mathrm{MTCpA}=$ mean total citation per article. $\mathrm{MTCpY}=$ mean total citations per year. $\mathrm{CY}=$ citable years. 
Table 3. Top 10 highly-cited articles on LoMars research.

\begin{tabular}{|c|c|c|c|c|c|c|}
\hline $\mathbf{R}$ & TC & APYC & PY & Article Title & Journal/5YIF & Reference \\
\hline 1 & 312 & 52.0 & 2015 & $\begin{array}{l}\text { Spectral evidence for hydrated salts } \\
\text { in recurring slope lineae on Mars }\end{array}$ & $\begin{array}{l}\text { Nature } \\
\text { Geoscience/ } \\
15.781\end{array}$ & OJHA et al. 2015 \\
\hline 2 & $\begin{array}{l}119 \\
9\end{array}$ & 48.0 & 1996 & $\begin{array}{l}\text { Search for past life on Mars: } \\
\text { Possible relic biogenic activity in } \\
\text { Martian meteorite ALH84001 }\end{array}$ & $\begin{array}{l}\text { Science/ } \\
44.372\end{array}$ & MCKAY et al. 1996 \\
\hline 3 & 124 & 41.3 & 2018 & $\begin{array}{l}\text { Radar evidence of subglacial liquid } \\
\text { water on Mars }\end{array}$ & $\begin{array}{l}\text { Science/ } \\
44.372\end{array}$ & OROSEI et al. 2018 \\
\hline 4 & 642 & 40.1 & 2005 & $\begin{array}{l}\text { Phyllosilicates on Mars and } \\
\text { implications for early Martian } \\
\text { climate }\end{array}$ & Nature/ 45.819 & POULET et al. 2005 \\
\hline 5 & 267 & 29.7 & 2012 & $\begin{array}{l}\text { The sample analysis at Mars } \\
\text { investigation and instrument suite }\end{array}$ & $\begin{array}{l}\text { Space Science } \\
\text { Reviews/ } \\
7.885\end{array}$ & $\begin{array}{l}\text { MAHAFFY et al. } \\
2012\end{array}$ \\
\hline 6 & 148 & 21.1 & 2014 & $\begin{array}{l}\text { Recurring slope lineae in equatorial } \\
\text { regions of Mars }\end{array}$ & $\begin{array}{l}\text { Nature } \\
\text { Geoscience/ } \\
15.781\end{array}$ & $\begin{array}{l}\text { MCEWEN et al. } \\
2014\end{array}$ \\
\hline 7 & 404 & 20.2 & 2001 & $\begin{array}{l}\text { Evidence for recent climate change } \\
\text { on Mars from the identification of } \\
\text { youthful near-surface ground ice }\end{array}$ & Nature/ 45.819 & $\begin{array}{l}\text { MUSTARD et al. } \\
2001\end{array}$ \\
\hline 8 & 496 & 17.7 & 1993 & $\begin{array}{l}\text { A model for the hydrologic and } \\
\text { climatic behavior of water on Mars }\end{array}$ & $\begin{array}{l}\text { JGR Planets/ } \\
3.858\end{array}$ & CLIFFORD 1993 \\
\hline 9 & 272 & 17.0 & 2005 & $\begin{array}{l}\text { Sedimentary rocks at Meridiani } \\
\text { Planum: Origin, diagenesis, and } \\
\text { implications for life on Mars }\end{array}$ & EPSL/ 5.273 & $\begin{array}{l}\text { SQUYRES \& } \\
\text { KNOLL, } 2005\end{array}$ \\
\hline 10 & 122 & 15.3 & 2013 & $\begin{array}{l}\text { Impact-generated hydrothermal } \\
\text { systems on Earth and Mars }\end{array}$ & Icarus/ 3.345 & $\begin{array}{l}\text { OSINSKI et al. } \\
2013\end{array}$ \\
\hline
\end{tabular}

Abbreviations: $\mathrm{R}=$ article rank. $\mathrm{TC}=$ total citations. $\mathrm{APYC}=$ average per year citations. $\mathrm{PY}=$ publication year. $5 \mathrm{YIF}=5$-year impact factor. JGR = Journal of Geophysical Research.

Influential Authors and Countries

The authors' productivity in LoMars research has been evaluated using H-, G-, and M-index based on the number of citations (Table 4). Six of the Top 10 most influential authors belong to the USA (majority represent NASA; Table 4), and the other four authors are affiliated with institutions in European countries including UK, Germany, Spain, and Italy (i.e., G7 countries). McKay C. P. is strongly ranked at first position among the Top 10 authors in total number of publications, total citations, H-, and G-Index (Table 4). However, M-Index (e.g., H-Index divided by the number of years the scientist has been active) is relatively lower because the author has been active for 32 years (since 1989). USA is also leading the world in two categories: Multiple Country Publication (MCP) and Single Country Publication (SCP; Fig. 3a). NASA ranked $6^{\text {th }}$ in the list of most collaborative institutions in the worldwide (Nature Index 2016), as evidenced by the highest number of documents for MCP category (Fig. 3a), suggesting the dominance of the USA in collaborative research in the field of LoMars in particular and planetary research in general (Table 2). Furthermore, USA also tops the list of highly-cited countries on LoMars research (Fig. 3b). 
Table 4. Top 10 most influential authors based on number of publications on LoMars research.

\begin{tabular}{|c|c|c|c|c|c|c|}
\hline Authors & Affiliation & NP & $\begin{array}{l}\text { H- } \\
\text { Index }\end{array}$ & $\begin{array}{l}\text { G- } \\
\text { Index }\end{array}$ & $\begin{array}{l}\text { M- } \\
\text { Index }\end{array}$ & TC \\
\hline McKay C. P. & NASA, USA & 29 & 17 & 29 & 0.53 & 1131 \\
\hline Westall F. & NASA, USA & 16 & 13 & 16 & 0.57 & 567 \\
\hline $\begin{array}{l}\text { Mancinelli R. } \\
\text { L. }\end{array}$ & NASA, USA & 14 & 11 & 14 & 0.34 & 326 \\
\hline $\begin{array}{l}\text { Schulze- } \\
\text { Makuch D. }\end{array}$ & $\begin{array}{l}\text { Technische } \\
\text { Universität, } \\
\text { Germany }\end{array}$ & 14 & 9 & 14 & 0.60 & 275 \\
\hline Sephton M. A. & $\begin{array}{l}\text { Imperial College } \\
\text { London, UK }\end{array}$ & 14 & 6 & 12 & 0.46 & 149 \\
\hline Steele A. & $\begin{array}{l}\text { Carnegie Institute of } \\
\text { Science, USA }\end{array}$ & 13 & 12 & 13 & 0.52 & 873 \\
\hline Davila A. F. & NASA, USA & 10 & 9 & 10 & 0.69 & 418 \\
\hline Fairén A. G. & $\begin{array}{l}\text { Centro de } \\
\text { Astrobiología, Spain }\end{array}$ & 10 & 8 & 10 & 0.57 & 353 \\
\hline Farmer J. D. & $\begin{array}{l}\text { Arizona State } \\
\text { University, USA }\end{array}$ & 10 & 8 & 10 & 0.35 & 598 \\
\hline Fonti S. & $\begin{array}{l}\text { Università del } \\
\text { Salento, Italy }\end{array}$ & 10 & 6 & 10 & 0.29 & 678 \\
\hline
\end{tabular}

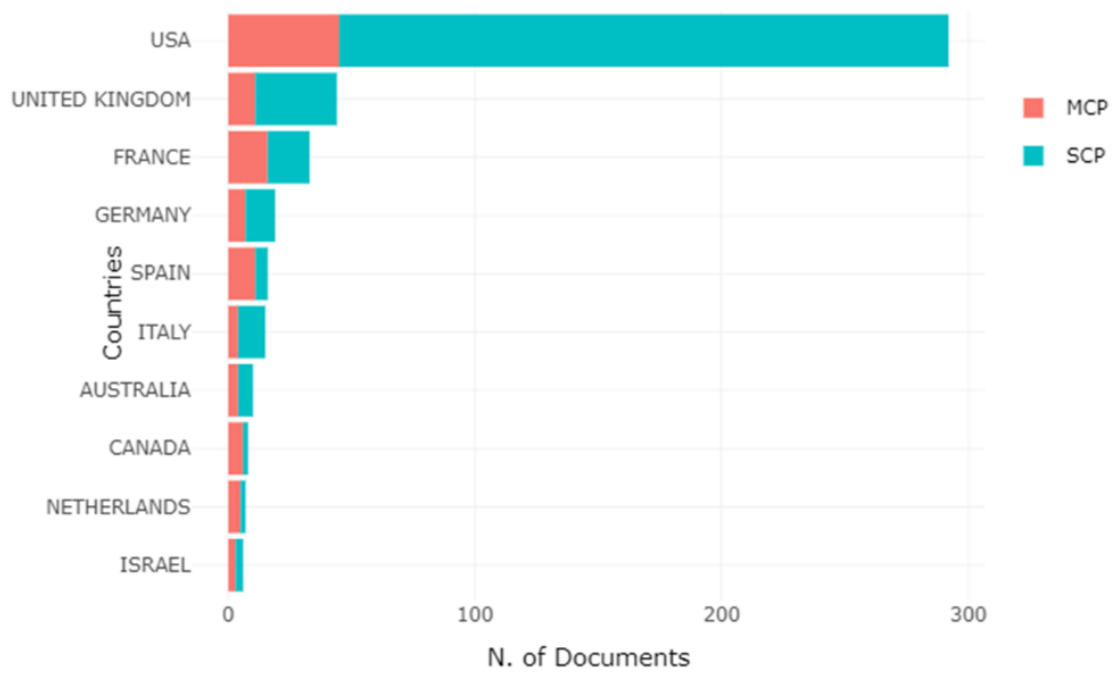

Figure 3a. The country of affiliation of the corresponding author (MCP: Multiple Country Publication - Co-authors' affiliations are in various countries, SCP: Single Country Publication -All authors' affiliations are in the same country). 


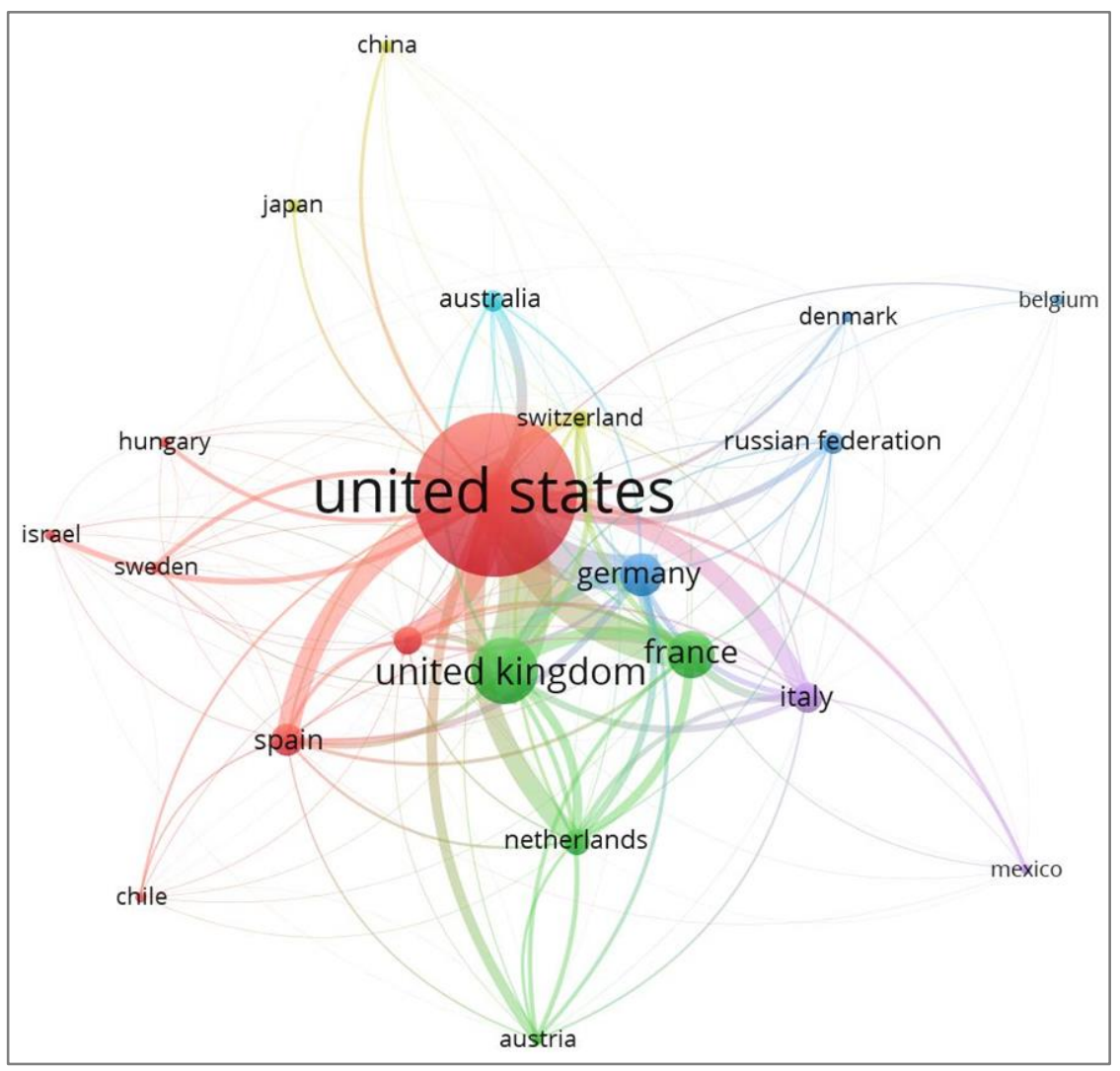

Figure 3b. Top cited countries with a minimum of five citations. Most of the G7 countries (the US, Japan, Germany, U.K., France, Italy, and Canada) are ranked in the Top 10.

\section{Collaborative Research}

Despite a substantial difference between the number of documents as multiple country publication (i.e., co-authors' affiliations are in various countries; MCP) and single country publication (i.e., all authors' affiliations are in the same country; SCP) for the USA, it still leads the list of the Top 10 countries ranked in terms of the affiliation of the corresponding author (Fig. 3a). If we consider MCP as a proxy for the measure of collaborative research, then the USA would be the most collaborative country in LoMars research (Fig. 4). Most of the other top-ranking countries belong to G7 nations, supporting the notion that scientific collaborations are directly related to the scientific infrastructure, basic research, and collaborative publication output.

For instance, China is leading the G7 countries in terms of publications since 1996 (HE, 2009) even though earlier it was not very prominent in LoMars research (Fig. 4). The author highlighted the policies including political, economic, educational, and scientific, have successfully emerged the country into a world giant in international scientific publications. Collaboration is one of the vital features of modern research, creating international opportunities for scientists as evidenced by the exponential growth of international collaboration publication output between China and G7 nations (HE, 2009). 
It is obvious that the contribution of African and Asian countries is either missing or sparse in LoMars research (Fig. 4). However, few countries representing Asia and Africa are recently emerging as new leaders in the planetary sciences. For example, the launch of Hope Probe on 19 July, 2020 by the United Arab Emirates (UAE) in collaboration with the Japan Aerospace Exploration Agency (JAXA) has already entered the Mars orbit on 9 February, 2021, a few days before the landing of the Mars 2020 Perseverance Rover on Martian surface (https://www.emiratesmarsmission.ae/). The Hope Probe will explore the different aspects of the Martian atmosphere for the first time to provide a complete compositional picture by using state-of-the-art instruments including Emirates Mars Infrared Spectrometer (EMIRS), Emirate Exploration Imager (EXI), and Emirates Mars Ultraviolet Spectrometer (EMUS). Furthermore, Tianwen-1 robotic spacecraft to Mars, China's first interplanetary mission, was launched on 23 July, 2020 by the China National Space Agency (CNSA) and successfully entered the Martian orbit on 10 February, 2021 to study the target site for the rover landing projected on May 2021. The scientific objectives of this rover include the study of Martian geology focusing on the internal structure of the planet, identification of minerals and rocks, atmosphere, and searching for signs of the presence of water by using 13 scientific instruments (https://en.wikipedia.org/wiki/Tianwen-1). These missions may exponentially increase the number of international collaborative research publications on LoMars and related topics in the coming years. Recently, it has been observed that international collaborations might not be beneficial unless an underdeveloped partner has some sort of local research capacity to benefit from the developed counter partner (SCARAZZATI \& WANG, 2019). Collaborative research is generally based on share of knowledge, skills, and techniques among the partners, leading to economic development and growth (LUUKKONEN et al. 1992; KATZ \& MARTIN, 1997). However, scientifically developed partners do not seek the same collaborations as those in the scientifically underdeveloped partners (SCARAZZATI \& WANG, 2019). It is said that the potential of planetary and space sciences (PSS) in Africa has been largely remained untapped because of a widespread misperception in African countries that funding fundamental science costs more to the society than do any benefit (BARATOUX et al. 2017). Despite the emergence of PSS in Africa by starting several PSS projects for regional research capacity building, the research groups are still scattered and underfunded. A piece of evidence comes from the publication survey (i.e., 2000-2015), revealing that only less than $1 \%$ of the worldwide output of scientific papers have been published in the four PSS representative journals (e.g., Icarus, Journal of Geophysical Research: Planets, Journal of Geophysical Research: Space Physics, and Meteoritics \& Planetary Science) despite Africa representing more than 15\% of the world's population (BARATOUX et al. 2017). However, there are numerous PSS developments in different regions of Africa, which are promising for the future and nurture of fundamental science related to PSS. For example, the South African National Space Agency and South African Astronomical Observatory are actively working in the PSS domain. Soon, world's largest radio telescope, Square Kilometre Array (SKA), will be established in the deserts of South Africa and Australia (BARATOUX et al. 2017). Morocco has been famous for various meteorite finds and impact studies (CHENNAOUI AOUDJEHANE et al. 2016), attracting international scientists through conferences and outreach activities (e.g., Space Bus Morocco). Furthermore, the Ibn Battuta Center and first astronomical observatory in Marrakesh have been established to test instruments related to Martian exploration and observation of meteorite impacts on the moon (AIT MOULAY LARBI et al. 2015) along with the search for exoplanets, 
respectively (BENKHALDOUN et al. 2005; GILLON et al. 2017). Algeria is also focusing on meteorites and impact craters with the help of international collaborations (LAMALI et al. 2016; SAHOUI et al. 2016). Since 2015, the Arabian Geosciences Union have launched a special section on planetary science and astrobiology for PSS scientists across northern Africa and the Middle East. The Sultanate of Oman has been the hub for the discovery of various types of meteorites (ALI et al. 2017a, 2017b) including Martian meteorites, such as Dhofar 019, Sayh al Uhaymir (SaU) 005, and SaU 008 (ALI et al. 2016, 2017c, 2018), can use it as a catalyst to initiate regional collaborations to promote PSS.

The most collaborative author on LoMars research (McKay C. P.; Fig. 5) has recently discussed five prerequisites for detecting life on other worlds, including Mars (MCKAY 2020). The author observed upon the following convincing evidences to be targeted in the pursuit of search for life beyond planet Earth: i) signs of liquid water of suitable salinity, ii) carbon in the water, iii) biologically available nitrogen in the water, iv) biologically useful energy in the water, and v) organic material that can possibly be of biological origin and applicable strategy for sampling this material (MCKAY, 2020).

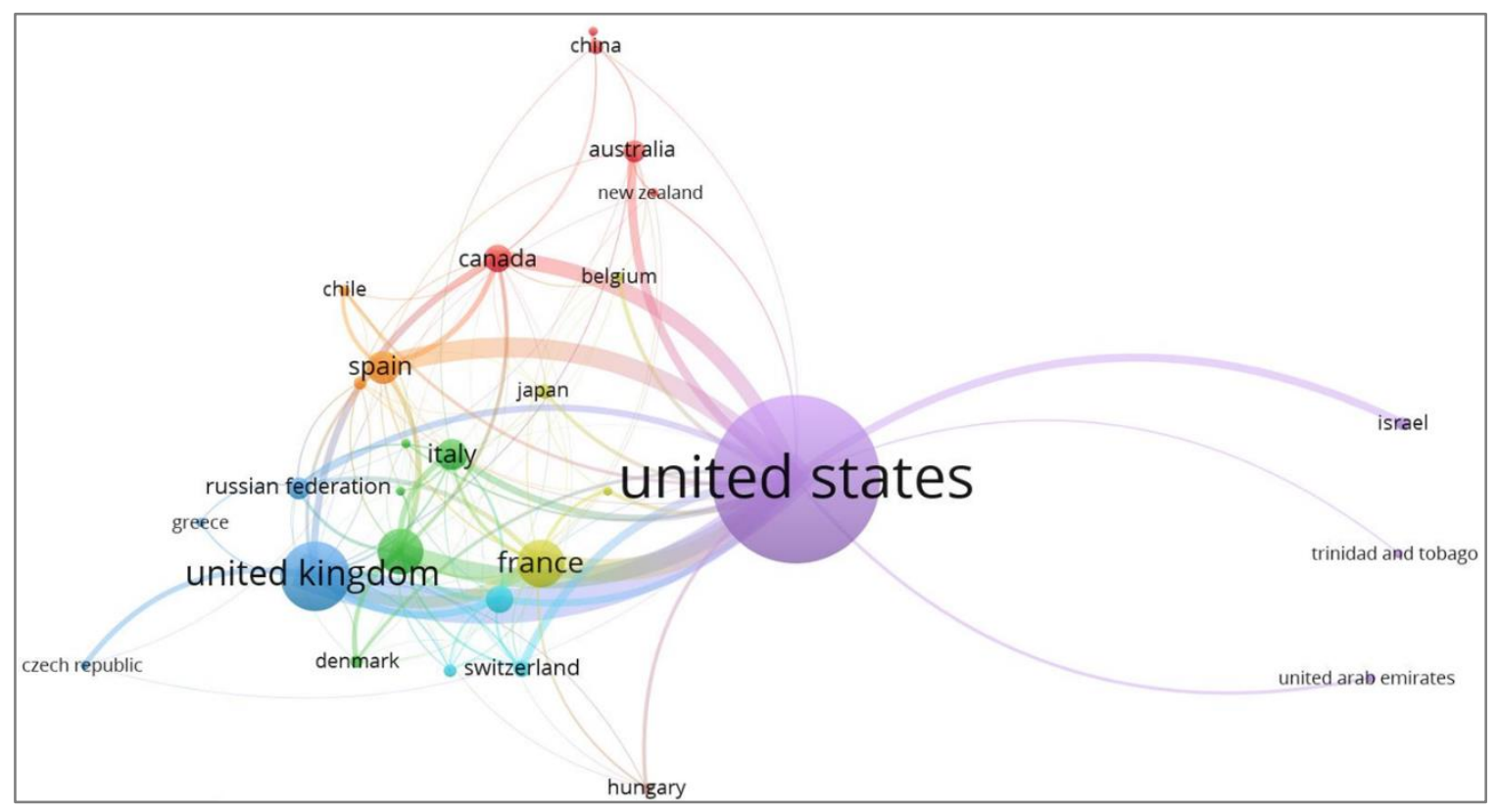

Figure 4. Co-authoring countries who published a minimum of two articles collaboratively. The USA is the main collaborator with the rest of the world working on LoMars research particularly in Europe and Asia. Most of the G7 countries (the USA, Japan, Germany, U.K., France, Italy, and Canada) are ranked in the Top 10. 


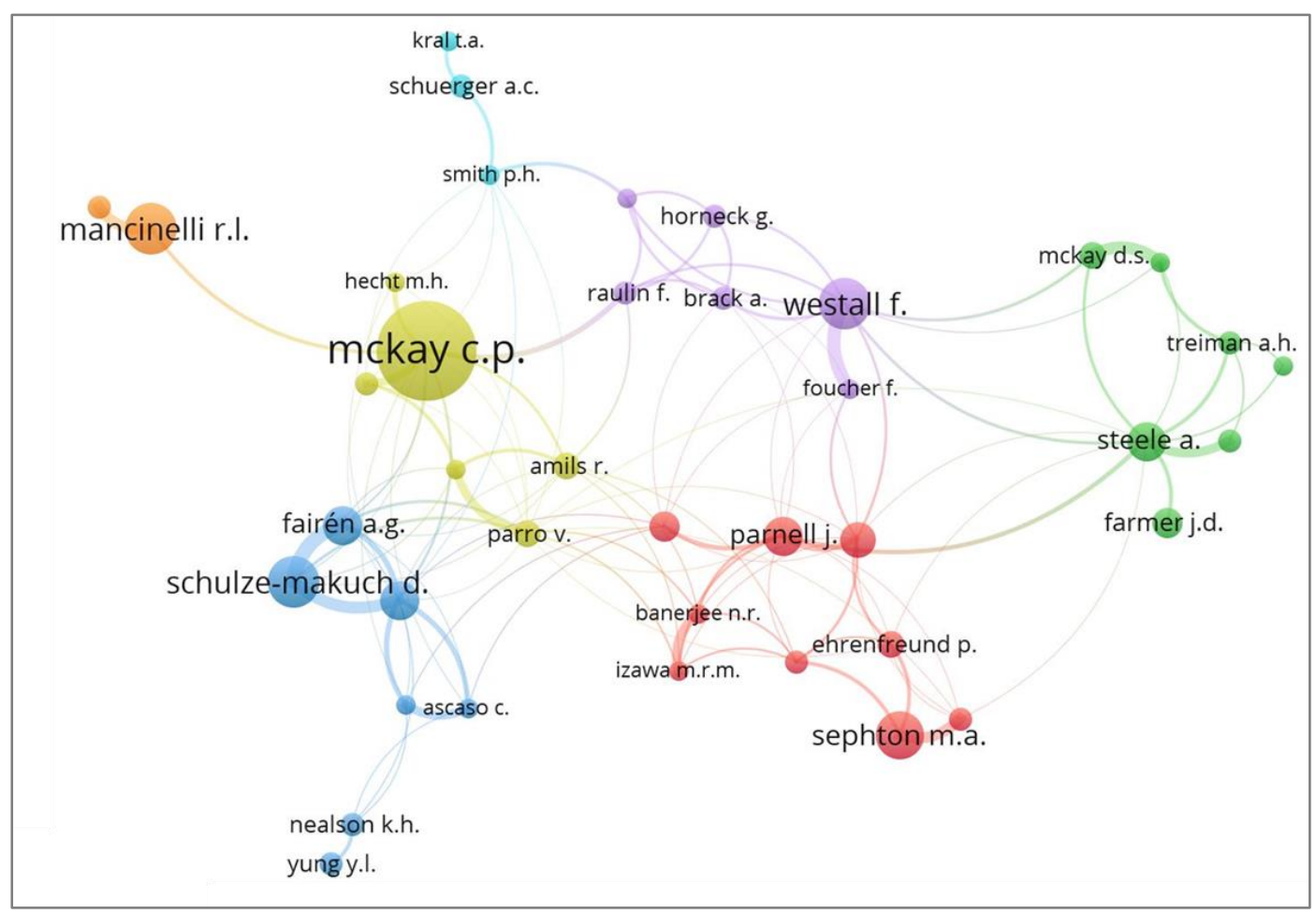

Figure 5. Co-authors with a minimum of five collaborative publications on LoMars research.

\section{Productive Journals}

According to the Bradford law (the estimation of exponentially diminishing returns of searching for references in scientific journals), 162 journals have been distributed into three zones with roughly one-third of all the articles in each zone (Fig. 6a). Zone 1 comprises of four core journals: Icarus, Astrobiology, Planetary and Space Science, and Advances in Space Research. This zone collectively published 229 papers (Figure 6a) which have been cited for a total of 3698 times (Figure 6b). The total number of citations in Zones1, 2 and 3 are distributed in an increasing order as $3698<5302<13239$, respectively (Figure 5b). However, number of citations per journal is decreasing for Zones 1,2 and 3 in the order of 925>331>93, respectively.

Among the list of journals in Table 5, Icarus is one of the oldest journals after Science and Nature. The top 15 journals have published $62.7 \%$ of the total articles about LoMars research. The most productive journal Icarus $(11.4 \%)$ is marginally ahead of Astrobiology (11.1\%). Icarus Journal is leading in all the aspects, including the number of publications (NP), the number of citations (CT), H-, and G-Index, but not M-Index (H-Index divided by the number of years since it published its first paper on LoMars) because it started publishing on LoMars since 1971 (Table 5).

Based on the total number of publications related to LoMars research, Icarus (75 publications), California Institute of Technology (55 publications), and McKay C. P. (29 publications) have been categorized as the most influential journal, institute, and the author, respectively (Fig. 7). The Elsevier's Journal Icarus is mainly aligned for the publication of original contributions in the field of Solar System studies with an impact factor of 3.513 (2019; 
Clarivate Analytics, 2020). Caltech was founded as Throop University in 1891 in Pasadena, California, and later renamed as California Institute of Technology (i.e., Caltech) in 1920. So far, this institute has produced 40 Nobel Laureates in different disciplines of natural sciences. The Jet Propulsion Laboratory (JPL) was founded by Caltech in the 1930s, and is managed by NASA since 1958. The highly influential author for LoMars research, McKay C. P., is a senior scientist affiliated with NASA.

Table 5. Most productive journals related to LoMars research.

\begin{tabular}{lllllll}
\hline Source & $\begin{array}{l}\text { H- } \\
\text { Index }\end{array}$ & $\begin{array}{l}\text { G- } \\
\text { Index }\end{array}$ & $\begin{array}{l}\text { M- } \\
\text { Index }\end{array}$ & TC & NP & $\% \mathbf{P}$ \\
\hline Icarus & 34 & 59 & 0.68 & 3660 & 75 & 11.4 \\
Astrobiology & 27 & 41 & 1.35 & 1923 & 73 & 11.1 \\
Planetary and Space Science & 19 & 32 & 0.42 & 1087 & 44 & 6.7 \\
Advances in Space Research & 15 & 24 & 0.43 & 651 & 37 & 5.6 \\
Journal of geophysical Research E: Planets & 24 & 35 & 0.96 & 1811 & 35 & 5.3 \\
International Journal of Astrobiology & 14 & 20 & 0.74 & 465 & 29 & 4.4 \\
Science & 16 & 22 & 0.27 & 2869 & 22 & 3.3 \\
Geophysical Research Letters & 14 & 20 & 0.64 & 513 & 20 & 3.0 \\
Nature & 13 & 16 & 0.22 & 1832 & 16 & 2.4 \\
Earth and Planetary Science Letters & 10 & 14 & 0.63 & 655 & 14 & 2.1 \\
Geochimica et Cosmochimica Acta & 10 & 12 & 0.42 & 431 & 12 & 1.8 \\
Acta Astronautica & 6 & 8 & 0.14 & 74 & 10 & 1.5 \\
Geology & 10 & 10 & 0.53 & 398 & 10 & 1.5 \\
Origins of Life and Evolution of the & 8 & 9 & 0.22 & 497 & 9 & 1.4 \\
Biosphere & & & & & & \\
Meteoritics and Planetary Science & 6 & 8 & 0.26 & 274 & 8 & 1.2 \\
\hline
\end{tabular}

Abbreviations: $\mathrm{TC}=$ total citations. $\mathrm{NP}=$ number of publications. $\% \mathrm{P}=$ percent publications.

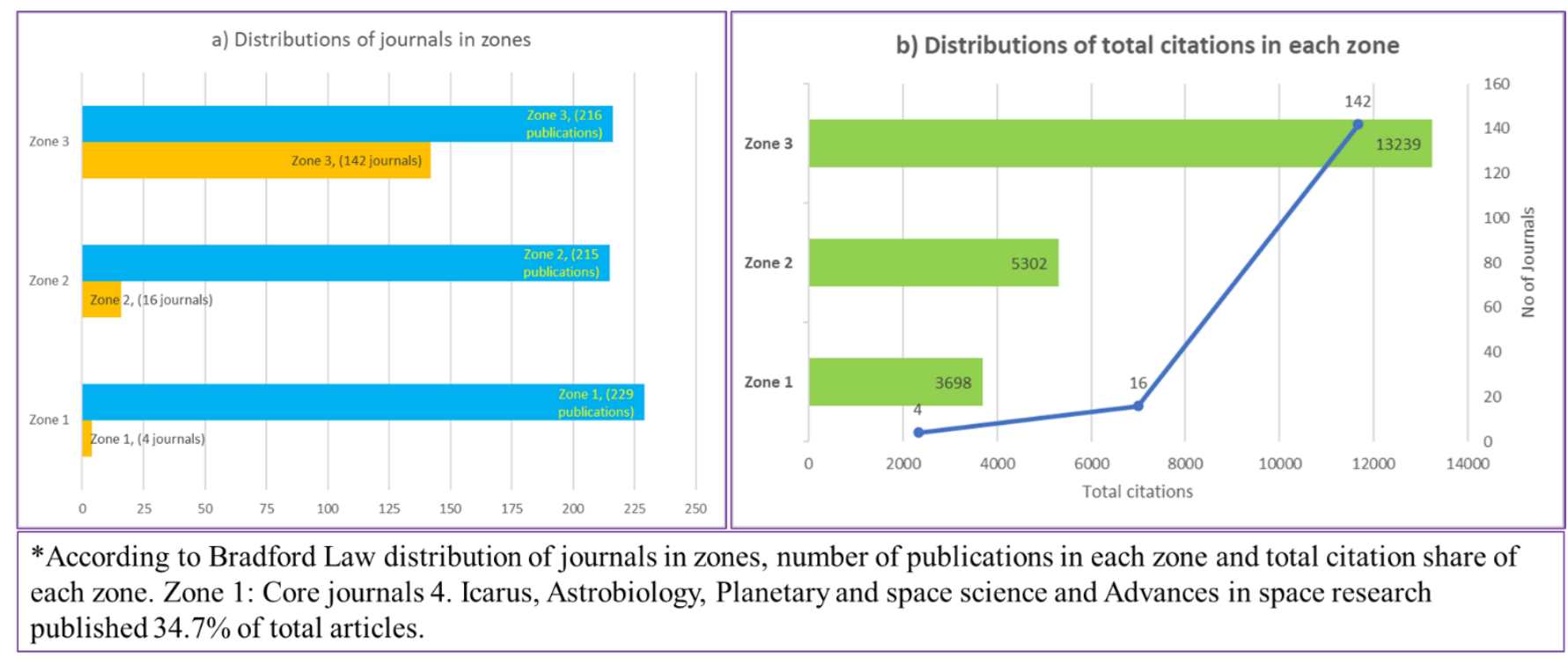

Figure 6. Distribution of scientific journals according to Bradford Law and the citation share of each zone. 


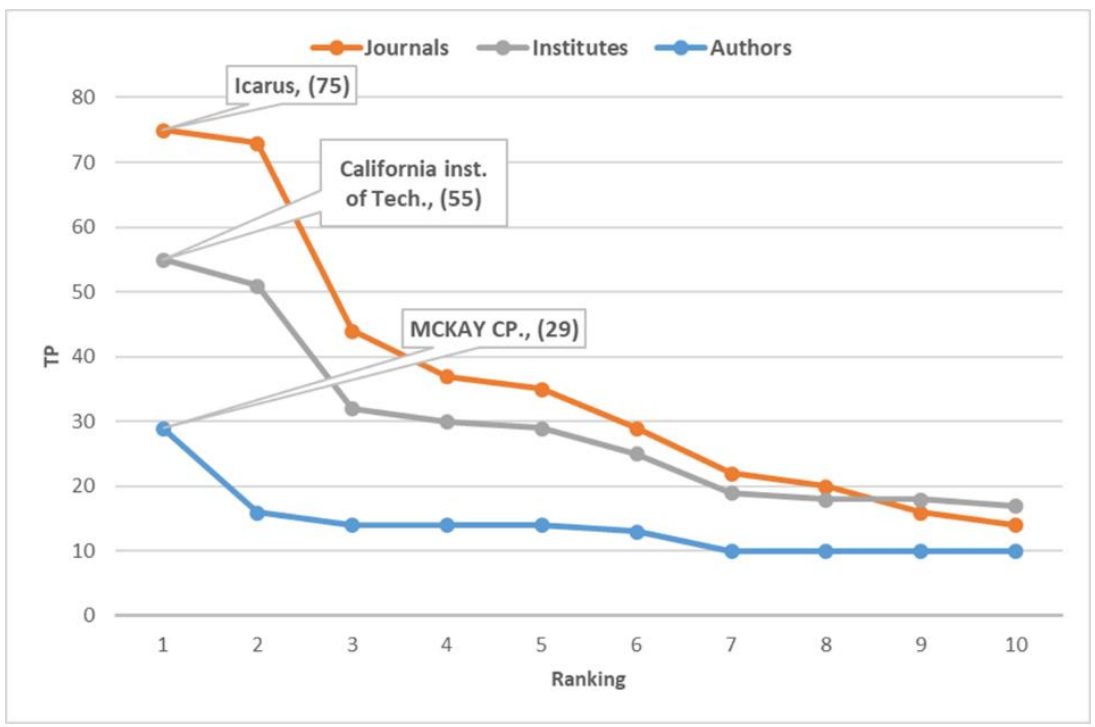

Figure 7. Highly influential journal, institute and author based on the total number of publications in LoMars research.

\section{Keywords}

According to Figure 8, the top five keywords (e.g., Mars, astrobiology, exobiology, Mars' surface, life on Mars) are directly related either to the planet under discussion or study of life on it. The Mars 2020 Rover is specially designed to study the past and present life on Mars and future sample return missions are of utmost importance to understand LoMars. So far, meteorites have been investigated for this purpose, but due to their lengthy and severe journey, most of the sedimentary materials might have been lost as well as followed by possible terrestrial contamination. Thus, it is expected that pristine samples returning from the surface and subsurface of Mars in the future will most likely affect the trend of selecting keywords such as surface, mineralogy, carbonates, habitability, and climate (Fig. 8). 


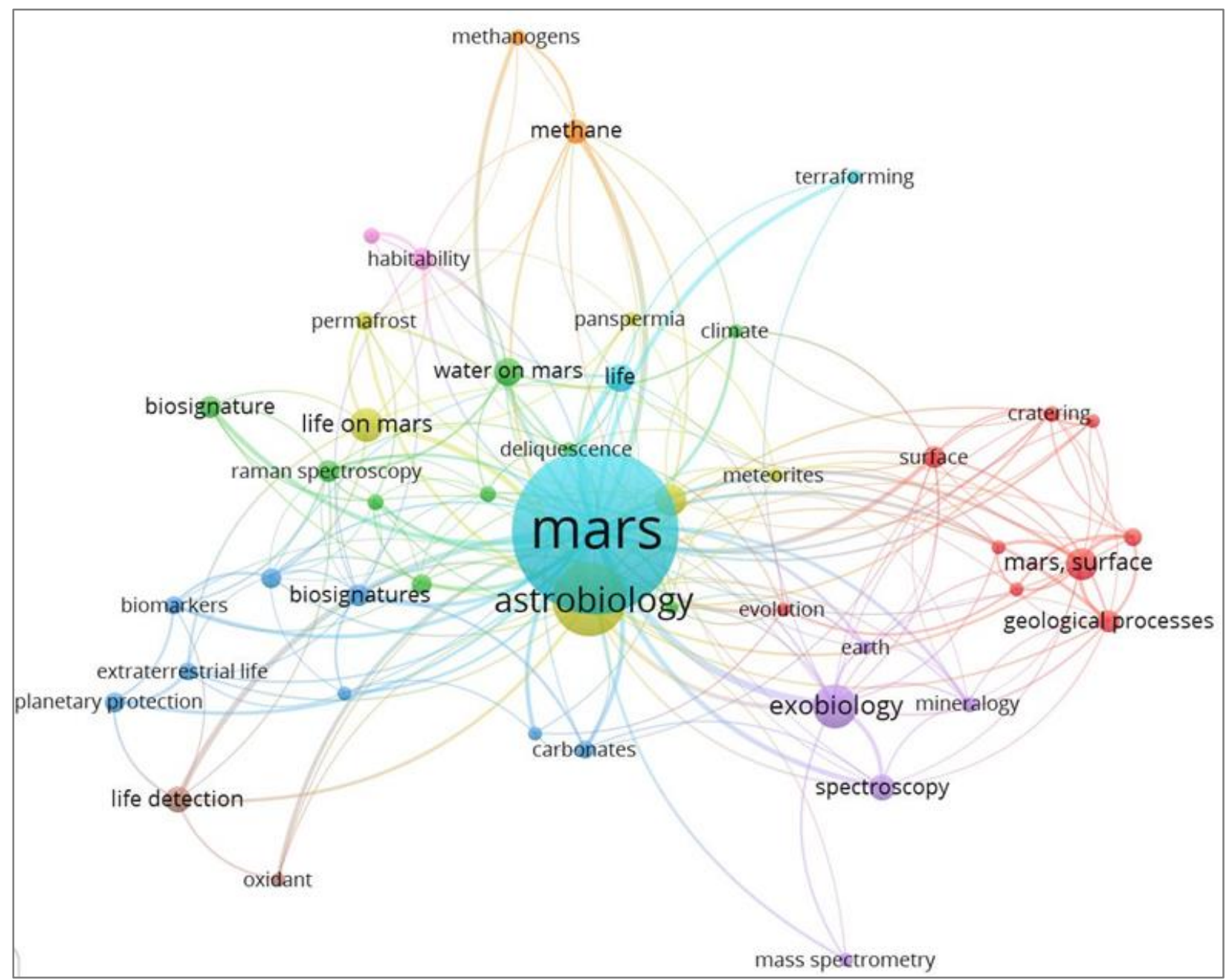

Figure 8. Frequency of occurrence of different keywords (co-occurrence authors' keywords network) in LoMars research.

\section{Conclusions}

Since the middle of the $20^{\text {th }}$ century, a search for life on other planets, especially Mars, started with the publication of scientific papers in prestigious journals in the early 1960s. It is observed that scientific publications throughput is closely related to the launch of different rovers by the National Aeronautics and Space Administration (NASA), which can be used as a proxy to predict the amount of future research on Mars after the landing of the Mars 2020 Perseverance Rover in 2021. This trend would equally be reinforced by parallel missions by UAE Space Agency and China National Space Agency. To date, given the availability of infrastructure and human scientific resources, USA dominated the citations and collaborations with the rest of the world on Mars research. Most of the top-cited papers report results of observational and theoretical research. However, the highly cited paper (MCKAY D. S. et al. 1996) is based on analytical studies of a unique Martian meteorite (i.e., Allan Hills 84001), suggesting that the sample return mission associated with the Perseverance Rover would possibly enhance the LoMars research exponentially in the future. According to the bibliometric analysis of a total number of publications on LoMars, Caltech, McKay C. P., and Icarus are turned out to be the most influential institute, author, and journal, respectively. 
The highly ranked institute and the author in LoMars research are closely related to NASA, indicative of the dominance of the organization.

\section{Acknowledgments}

\section{References}

AIT MOULAY LARBI, M., DAASSOU, A., BARATOUX, D., BOULEY, S., BENKHALDOUN, Z., LAZREK, M., GARCIA, R., COLAS, F. (2015), First lunar flashes observed from Morocco (ILIAD Network): Implications for lunar seismology, Earth Moon Planets, 115 : 1-21.

ALI, A., JABEEN, I., GREGORY, D., VERISH, R., BANERJEE, N. R. (2016), New triple oxygen isotope data of bulk and separated fractions from SNC meteorites: Evidence for mantle homogeneity of Mars. Meteoritics \& Planetary Science, 51 : 981-995.

ALI, A., NASIR, S., JABEEN, I., AL RAWAS, A. (2017a), Chemical and oxygen isotopic properties of ordinary chondrites (H5, L6) from Oman: Signs of isotopic equilibrium during thermal metamorphism. Meteoritics \& Planetary Science, 52 (10) : 2097-2112.

ALI, A., NASIR, S., JABEEN, I., AL RAWAS, A. (2017b), Geochemical and O-isotope perspective of a new R chondrite Dhofar 1671: Affinity with ordinary chondrites. Meteoritics \& Planetary Science, 52(9) : 1991-2003. ALI, A., NASIR, S., JABEEN, I., AL RAWAS, A. (2017c), Review of the Sayh al Uhaymir (SaU) 005, plus pairings, Martian meteorite from Al Wusta, Oman. SQU Journal for Science, 22 (1) : 29-39.

ALI, A., JABEEN, I., NASIR, S., BANERJEE, N. R. (2018), Oxygen isotope thermometry of DaG 476 and SaU 008 Martian meteorites: Implications for their origin. Geosciences (Special Issue: Martian Meteorites). https://doi.org/10.3390/geosciences8010015

ARIA, M., CUCCURULLO, C. (2017), bibliometrix: An R-tool for comprehensive science mapping analysis. Journal of Informetrics, 11: 959-975.

BARATOUX, D., CHENNAOUI AOUDJEHANE, H., GIBSON, R., LAMALI, A., REIMOLD, W. U., SELORM SAPAH, M., CHARAF CHABOU, M., HABARULEMA, J. B., JESSELL, M. W., MOGESSIE, A., BENKHALDOUN, Z., NKHONJERA, E., MUKOSI, N. C., KAIRE, M., ROCHETTE, P., SICKAFOOSE, A., MARTÍNEZ-FRÍAS, J., HOFMANN, A., FOLCO, L., ROSSI, A. P., FAYE, G., KOLENBERG, K., TEKLE, K., BELHAI, D., ELYAJOURI, M., KOEBERL, C., ABDEEN, M. M. (2017), The state of planetary and space sciences in Africa, Eos, 98. https://doi.org/10.1029/2017EO075833

BENKHALDOUN, Z., ABAHAMID, A., EL AZHARI, Y., LAZREK, M. (2005), Optical seeing monitoring at the Oukaïmeden in the Moroccan High Atlas Mountains: First statistics. Astronomy \& Astrophysics, 441(2) : 839-843. BENNER, S. A., DEVINE, K. G., MATVEEVA, L. N., POWELL, D. H. (2000), The missing organic molecules on Mars. Proceedings of the National Academy of Sciences of the United States of America, 97 (6) : 2425-2430. BOAMAH, D., KOEBERL, C. (2007), The Lake Bosumtwi impact structure in Ghana: A brief environmental assessment and discussion of ecotourism potential. Meteoritics and Planetary Science, 42 : 561-567. BOGARD, D. D., JOHNSON, P. (1983), Martian gases in an Antarctic meteorite? Science, 221 : 651-654. 
CHENNAOUI AOUDJEHANE, H., EL KERNI, H., REIMOLD, W. U., BARATOUX, D., KOEBERL, C., BOUlEY, S., AOUDJEHANE, M. (2016), The Agoudal (High Atlas Mountains, Morocco) shatter cone conundrum: A recent meteorite fall onto the remnant of an impact site, Meteoritics \& Planetary Science, 51(8) : 1497-1518.

CLIFFORD, S. M. (1993), A model for the hydrologic and climatic behaviour of water on Mars. JGR Planets, 98 (E6) : 10973-11016. https://doi.org/10.1029/93JE00225

GILlON, M., TRIAUD, A. H. M. J., DEMORY, B. -O., JEHIB, E., AGOL, E., DECK, K. M., LEDERER, S. M., DE WIT, J., BURDANOV, A., INGALLS, J. G., BOLMONT, E., LECONTE, J., RAYMOND, S. N., SELSIS, F., TURBET, M., BARKAOUI, K., BURGASSER, A., BURLEIGH, M. R., CAREY, S. J., CHAUSHEV, A., COPPERWHEAT, C. M., DELREZ, L., FARNANDES, C. S., HOLDSWORTH, D. L., KOTZE, E. J., GROOTEL, V. V., ALMLEAKY, Y., BENKHALDOUN, Z., MAGAIN, P., QUELOZ, D. (2017), Seven temperate terrestrial planets around the nearby ultracool dwarf star TRAPPIST-1, Nature, 542 :456-460.

HAWRYLEWICZ, E. J., HAGEN, C., TOLKACZ, V., EHRLICH, R. (1967), Effect of reduced barometric pressure on water availability related to microbial growth. Life Sciences and Space Research, 5 : 174-186.

HE, T. (2009), International scientific collaboration of Chine with the G7 countries. Scientometrics, 80 (3) : 571 582 .

JAKOSKY, B.M., SHOCK, E. L. (1998), The biological potential of Mars, the early Earth, and Europa. Journal of Geophysical Research, 103 (E8) : 19,359-19,364.

KATZ, J. S., MARTIN, B. R. (1997), What is research collaboration? Research Policy, 26 : 1-18. LAMAli, A., ROCHETTE, P., MERABET, N., ABTOUT A., MAOUCHE, S., GATTACCECA, J., FERRIÈRE, L., HAMOUDI, M., ASTER TEAM, MEZIANE, E. H., AYACHE M. (2016), Geophysical and magneto-structural study of the Maâdna structure (Talemzane, Algeria): Insights on its age and origin. Meteoritics \& Planetary Sciience, 51(12) : 2249-2273.

LEVIN, G. V., HEIM, A. H., CLENDENNING, J. R., THOMPSON, M-F. (1962), “Gulliver”-A quest for life on Mars. Science, $138: 114-121$.

LEVIN, G. V., STRAAT, P. A. (1976), Viking labelled release biology experiment: Interim results. Science, 194 : 1322-1329.

LUUKKONEN, T., PERSSON, O., SIVERTSEN, G. (1992), Understanding patterns of international scientific collaboration. Science, Technology and Human Values, 17(1) : 101-126.

MAHAFFY, P. R., WEBSTER, C. R., CABANE, M., CONRAD, P. G., COLL, P., ATREYA, S. K., ARVEY, R., BARCINIAK, M., BENNA, M., BLEACHER, L., BRINCKERHOFF, W. B., EIGENBRODE, J. L., CARIGNAN, D., CASCIA, M., CHALMERS, R. A., DWORKIN, J. P., ERRIGO, T., EVERSON, P., FRANZ, H., FARLEY, R., FENG, S., FRAZIER, G., FREISSINET, C., GLAVIN, D. P., HARPOLD, D. N., HAWK, D., HOLMES, V., JOHNSON, C. S., JONES, A., JORDAN, P., KELlOG, J., LEWIS, J., LYNESS, E., MALESPIN, C. A., MARTIN, D. K., MAURER, J., MCADAM, A. C., MCLENNAN, D., NOLAN, T. J., NORIEGA, M., PAVLOV, A. A., PRATS, B., RAAEN, E., SHEINMAN, O., SHEPPARD, D., SMITH, J., STERN, J. C., TAN, F., TRAINER, M., MING, D. W., MORRIS, R. V., JONES, J., GUNDERSEN, C., STEELE, A., WRAY, J., BOTTA, O., LESHIN, L. 
A., OWEN, T., BATTEL, S., JAKOSKY, B. M., MANNING, H., SQUYRES, S., NAVARRO-GONZÁLEZ, R., MCKAY, C. P., RAULIN, F., STERNBERG, R., BUCH, A., SORENSEN, P., KLINE-SCHODER, R., COSCIA, D., SZOPA, C., TEINTURIER, S., BAFFES, C., FELDMEN, J., FLESCH, G., FOROUHAR, S., GARCIA, R., KEYMEULEN, D., WOODWARD, S., BLOCK, B. P., ARNETT, K., MILLER, R., EDMONSON, C.,

GOREVAN, S., MUMM, E. (2012), The sample analysis at Mars investigation and instrument suite. Space Science Reviews, $170: 401-478$.

MARTY, T., VANSTONE, B., HAHN, T. (2020), News media analytics in finance: a survey. Accounting \& Finance, $60: 1385-1434$.

MCKAY, D. S., GIBSON JR., E. K., THOMAS-KEPRTA, K. L., VALI, H., ROMANEK, C. S., CLEMETT, S. J., CHILLIER, X. D. F., MAECHLING, C. R., ZARE, R. N. (1996), Search for past life on Mars: Possible relic biogenic activity in Martian meteorite ALH84001. Science, 273 : 924-930.

MCKAY, C. P. (2020), What is life-and when do we search for it on other worlds. Astrobiology, 20 (2) : 163-166.

MCEWEN, A. S., DUNDAS, C. M., MATTSON, S. S., TOIGO, A. D., OJHA, L., WRAY, J. J., CHOJNACKI, M., BYRNE, S., MURCHIE, S. L., THOMAS, N. (2014), Recurring slope lineae in equatorial regions of Mars. Nature Geoscience, 7 : 53-58.

MUSTARD, J. F., COOPER, C. D., RIFKIN, M. K. (2001), Evidence for recent climate change on Mars from the identification of youthful near-surface ground ice. Nature, $412: 411-414$.

OJHA, L., WILHELM, M. B., MURCHIE, S. L., MCEWEN, A. S., WRAY, J. J., HANLEY, J., MASSÉ, M., CHOJNACKI, M. (2015), Spectral evidence for hydrated salts recurring slope lineae on Mars. Nature Geoscience, 8 : 829-832.

OROSEI, R. LAURO, S. E., PETTINELLI, E., CICCHETTI, A., CORADINI, M., COSCIOTTI, B., DI PAOLO, F., FLAMINI, E., MATTEI, E., PAJOLA, M., SOLDOVIERI, F., CARTACCI, M., CASSENTI, F., FRIGERI, A., GIUPPI, S., MARTUFI, R., MASDEA, A., MITRI, G., NENNA, C., NOSCHESE, R., RESTANO, M., SEU, R. (2018), Radar evidence of subglacial kiquid water on Mars. Nature, $361: 490-493$.

OSINSKI, G. R., TORNABENE, L. L., BANERJEE, N. R., COCKELL, C. S., FLEMMING, R., IZAWA, M. R. M., MCCUTCHEON, J., PARNELl, J., PRESTON, L. J., PICKERSGILl, A. E., PONTERACT, A., SAPERS, H. M., SOUTHAM, G. (2013), Impact-generated hydrothermal systems on Earth and Mars. Icarus, 224 : 347-363. OYAMA, V. I., (1963), Use of gas chromatography for the detection of life on Mars. Nature, 200 : 1058-1059. PERIANES-RODRIGUES, A., WALTMAN, L., JAN VAN ECK, N. (2016), Constructing bibliometric networks: A comparison between full and fractional counting. Journal of Informetrics, 10 : 1178-1195.

POULET, F., BIBRING, J. -P., MUSTARD, J. F., GENDRIN, A., MANGOLD, N., LANGEVIN, Y., ARVIDSON, R. E., ONDET, B., GOMEZ, C., THE OMEGA TEAM (2005), Phyllosilicates on Mars and implications for early Martian climate. Nature, $438: 623-627$.

REA, D. G. (1963), Evidence for life on Mars. Nature, $200: 114-116$.

SHIRK, J. S., HASELTINE, W. A., PIMENTEL, G. C. (1965), Sinton bands: Evidence for deuterated water on Mars. Science, 147 : 48-49. 
SQUYRES, S. W., KNOLL, A. H. (2005), Sedimentary rocks at Meridiani Planum: Origin, diagenesis, and implications for life on Mars. Earth and Planetary Science Letters, 240 : 1-10.

SAHOUI, R., BELHAI, D., JAMBON, A. (2016), Impact-generated carbonate melts in the Talemzane impact structure (Laghouat, Algeria), Arabian Journal of Geosciences, 9 : 641, https://doi.org/10.1007/s12517-016-2665-6 SCARAZZATI, S., WANG, L. (2019), The effect of collaboration on scientific research output: the case of nanoscience in Chinese regions. Scientometrics, $121: 839-868$.

SKIDMORE, M. L., FOGHT, J. M., SHARP, M. J. (2000), Microbial life beneath a High Arctic Glacier. Applied and Environmental Microbiology, 66 (8) : 3214-3220.

SLEEP, N. H., ZAHNLE, K. (1998), Refugia from asteroid impacts on early Mars and the early Earth. Journal of Geophysical Research, 103 (E12) : 28,529-28,544.

WYNN-WILLIAMS, D. D., EDWARDS, H. G. M. (2000), Proximal analysis of regolith habitats and protective biomolecules in situ by Laser Raman Spectroscopy: Overview of terrestrial Antarctic habitats and Mars analogs.

Icarus, $144: 486-503$.

YEN, A. S., KIM, S. S., HECHT, M. H., FRANT, M. S., MURRAY, B. (2000), Evidence that the reactivity of the Martian soil is due to superoxide ions. Science, $289: 1909-1912$.

YOUNG, H., BELANGER, T., CORBIN, J. B., MAGRILL, R. M., PETERSON, F. M., THOMAS, D. M., TOROK, A. G., WOOLS, B. (1983). The ALA Glossary of Library and Information Science. Chicago: American Library Association. 